\title{
Association between glomerular filtration rate (measured by high-performance liquid chromatography with iohexol) and plasma oxalate
}

Associação entre taxa de filtração glomerular (medida por cromatografia liquida de alto desempenho com iohexol) e oxalato plasmático

\section{Authors}

Luciano da Silva Selistre ${ }^{1}$

Pierre Cochat ${ }^{2}$

Dener lizot Rech ${ }^{1}$

François Parant ${ }^{3}$

Vandréa Carla de Souza ${ }^{1}$

Laurence Dubourg ${ }^{4}$

${ }^{1}$ Universidade de Caxias do Sul, Caxias do Sul, Brasil. ${ }^{2}$ Université Claude-Bernard Lyon, Centre de Référence des Maladies Rénales Rares Nephrogones, Service de Néphrologie et Rhumatologie Pédiatriques, Lyon, France.

${ }^{3}$ Hospices Civils de Lyon, GHS - Centre de Biologie Sud, UM Pharmacologie Toxicologie, F-69495, Pierre Bénite, France.

${ }^{4}$ Université Claude-Bernard, Groupement Hospitalier Edouard Herriot, Hospices Civils de Lyon, UMR 5305, Rhone-Alpes, Lyon, France.

Submitted on: 07/03/2017. Approved on: 08/31/2017.

Correspondence to: Luciano da Silva Selistre. E-mail: Isselist@ucs.br

DOI: 10.1590/1678-4685-JBN-3743

\section{Abstract}

Introduction: Secondary hyperoxalemia is a multifactorial disease that affects several organs and tissues in patients with native or transplanted kidneys. Plasma oxalate may increase during renal failure because it is cleared from the body by the kidneys. However, there is scarce evidence about the association between glomerular filtration rate and plasma oxalate, especially in the early stages of chronic kidney disease (CKD). Methods: A case series focuses on the description of variations in clinical presentation. A pilot study was conducted using a cross-sectional analysis with 72 subjects. The glomerular filtration rate (GFR) and plasma oxalate levels were measured for all patients. Results: Median (IQR) GFR was 70.50 [39.0; 91.0] mL/ $\min / 1.73 \mathrm{~m}^{2}$. Plasma oxalate was $<5.0$ $\mu \mathrm{mol} / \mathrm{L}$ in all patients with a GFR $>30$ $\mathrm{mL} / \mathrm{min} / 1.73 \mathrm{~m}^{2}$. Among the 14 patients with severe CKD (GFR $<30 \mathrm{~mL} / \mathrm{min} / 1.73$ $\mathrm{m}^{2}$ ) only 4 patients showed a slightly increased plasma oxalate level (between 6 and $12 \mu \mathrm{mol} / \mathrm{L}$ ). Conclusion: In non-primary hyperoxaluria, plasma oxalate concentration increases when GFR $<30 \mathrm{~mL} /$ $\min / 1.73 \mathrm{~m}^{2}$ and, in our opinion, values greater than $5 \mu \mathrm{mol} / \mathrm{L}$ with a GFR $>30$ $\mathrm{mL} / \mathrm{min} / 1.73 \mathrm{~m}^{2}$ are suggestive of primary hyperoxaluria. Further studies are necessary to confirm plasma oxalate increase in patients with low GFR levels $(<30 \mathrm{~mL} /$ $\min / 1.73 \mathrm{~m}^{2}$ ).

Keywords: Glomerular Filtration Rate; Hyperoxaluria; Chronic kidney disease.

\section{INTRODUCTION}

Oxalate, the ionic form of plasma oxalate $(\mathrm{POx})$, is an insoluble end-product of the metabolism of foods derived from various

\section{Resumo}

Introdução: A hiperoxalemia secundária é uma doença multifatorial que afeta vários órgãos e tecidos em pacientes com rins nativos ou transplantados. O oxalato plasmático pode aumentar durante a insuficiência renal porque é eliminado do corpo pelos rins. No entanto, há evidências escassas sobre a associação entre taxa de filtração glomerular e oxalato plasmático, especialmente nos estágios iniciais da doença renal crônica (DRC). Métodos: uma casuística centrada na descrição das variações na apresentação clínica. Foi realizado um estudo piloto a partir da análise transversal com 72 indivíduos. As taxas de filtração glomerular (TFG) e os níveis plasmáticos de oxalato foram medidos para todos os pacientes. Resultados: A TFG mediana (IIQ) foi de 70,50 [39,0; 91,0] mL/ $\mathrm{min} / 1,73 \mathrm{~m}^{2}$. O nível plasmático de oxalato foi $<5,0 \mu \mathrm{mol} / \mathrm{L}$ em todos os pacientes com TFG $>30 \mathrm{~mL} / \mathrm{min} / 1,73 \mathrm{~m} 2$. Entre os 14 pacientes com DRC grave (TFG $<30 \mathrm{~mL}$ / $\min / 1,73 \mathrm{~m}^{2}$ ), apenas quatro apresentaram ligeiro aumento do nível plasmático de oxalato (entre 6 e $12 \mu \mathrm{mol} / \mathrm{L}$ ). Conclusão: $\mathrm{Na}$ hiperoxalúria não primária, a concentração plasmática de oxalato aumenta quando TFG $<30 \mathrm{~mL} / \mathrm{min} / 1,73 \mathrm{~m}^{2}$ e, em nossa opinião, valores superiores a $5 \mu \mathrm{mol} / \mathrm{L}$ com TFG > 30 $\mathrm{mL} / \mathrm{min} / 1,73 \mathrm{~m}^{2}$ sugerem presença de hiperoxalúria primária. Estudos adicionais são necessários para confirmar o aumento do oxalato plasmático em pacientes com níveis baixos de TFG $\left(<30 \mathrm{~mL} / \mathrm{min} / 1,73 \mathrm{~m}^{2}\right)$.

Palavras-chave: Taxa de filtração glomerular; Hiperoxalúria; Doença renal crônica. animal and plant sources. Increase of $\mathrm{POx}$ and oxalosis, i.e., calcium oxalate deposition in tissues, can result in primary $(\mathrm{PH})$ or secondary hyperoxaluria $(\mathrm{SH}) .^{1,2} \mathrm{PHs}$ are a group of rare autosomal recessive 
metabolic disorders resulting in overproduction of oxalate, ${ }^{3}$ caused by the deficiency of three different enzymes and affecting a different intracellular organelle; ${ }^{1,2}$ the disorders are designated as $\mathrm{PH}$ types 1 , 2 , and 3 .

$\mathrm{SH}$ may occur either as a result of excessive ingestion of oxalate or oxalate precursors such as ethylene glycol or through decreased excretion of oxalate by the kidney. ${ }^{1}$ Excessive intake or increased absorption (intestinal disorders) of oxalate are widespread causes of urinary oxalate excretion increase and urolithiasis, but is rarely associated to an increase of POx and occurs under normal glomerular filtration rate (GFR). ${ }^{3-5}$ Thus, it cannot be further processed and is eliminated through normal filtration by the kidneys. In patients with chronic kidney disease (CKD), POx accumulates 10-30 times above normal levels as a result of its reduced excretion. Neither hemodialysis nor peritoneal dialysis can normalize POx levels in CKD patients; a $60 \%$ reduction is expected after a usual hemodialysis procedure, but POx was found to return to pre-dialysis levels within 48 h. $^{7}$ In contrast to PH, clinical manifestations of uremic oxalosis, such as nephrolithiasis, fractures, and bone pain, are uncommon. ${ }^{1,7}$

Nevertheless, a decline in GFR can increase POx and lead to cardiovascular complications. ${ }^{1,2,6,7}$ Salye et al. reported that $\mathrm{SH}$, i.e. renal and myocardial calcium oxalate deposition, in association with renal insufficiency is frequent and often extensive. ${ }^{8}$ In addition, they demonstrated that the incidence and severity of the oxalate deposition are related to the duration of renal insufficiency. ${ }^{8,9}$ Rechet et al. described an association between high levels of $\mathrm{POx}$ and endothelial injury leading to atherogenic effects by elevating intracellular calcium in endothelial cells. ${ }^{7}$ In transplanted kidneys, POx may overload the graft with potential tubular damage, affecting function. ${ }^{3,6,11}$

Therefore, we designed a pilot study with measured POx, measured GFR (mGFR, iohexol clearance), and estimated GFR (eGFR, plasma creatinine) in a series of patients with various stages of CKD.

\section{MATERIALS AND METHODS}

\section{PATIENTS}

For this pilot study, 72 CKD patients without $\mathrm{PH}$ were recruited between October 2014 and November 2014 to undergo GFR measurement (iohexol clearance). Ten patients presented with a severe CKD (stage IV-V) and POx without an mGFR. The sample was divided into groups according to GFR following the KDIGO classification. ${ }^{12}$

\section{OXALATE}

POx was measured on a Pentra 400 analyzer (HORIBA) by a modified sensitive oxalate oxidase colorimetric assay as reported by Petrarulo et al. Briefly, oxalate is converted to hydrogen peroxide, which, in the presence of peroxidase, reacts (POD) with MBTH (3-methyl-2-benzothiazolinone hydrazone) and DMAB (3-dimethylamino benzoic acid) forming a blue quinone compound. The color intensity is proportional to the concentration of $\mathrm{POx}$ in the sample and is read at $600 \mathrm{~nm}$ with $700 \mathrm{~nm}$ as reference wavelength. The optimization of the assay included plasma deproteinization by the sulfosalicylic acid (SSA) method and treatment with charcoal. The reference values are $<5 \mu \mathrm{mol} / \mathrm{L} .{ }^{13}$

\section{GFR MEASUREMENT BY IOHEXOL CLEARANCE}

Iohexol clearance was performed using a standard technique with single-bolus injection. Briefly, an i.v. injection of $6 \mathrm{~mL}$ (Omnipaque, $300 \mathrm{mg} / \mathrm{mL}$ ) was administered and 3 blood samples were drawn from the contra lateral arm after 120, 180, and 240 minutes. The mGFR was calculated from the slope of plasma concentrations using a one-compartment model corrected with the Bröchner-Mortensen formula. ${ }^{13}$ Plasma iohexol concentration was determined with an HPLC method adapted from Cavalier et al. ${ }^{15}$ The results were reported in $\mathrm{mL} / \mathrm{min} / 1.73 \mathrm{~m}^{2}$.

\section{EsTIMATION OF GFR}

Plasma creatinine (PCr) was measured by an IDMSstandardized enzymatic method, and eGFR was calculated with the CKD-EPI equation. ${ }^{12}$

\section{STATISTICAL ANALYSES}

We evaluated the distribution of continuous variables by calculating mean \pm standard deviation and categorical variables by number (percentage) in the whole data set, as well as in subgroups according to study population characteristics and candidates for living kidney donation. The error was calculated by subtracting eGFR from mGFR minus (mGFR - eGFR) for each individual; percent error was this difference relative to mGFR, i.e., (mGFR - eGFR)/mGFR. We computed the bias as the average error, which was appropriate for the distribution. 
Bias, an expression of systemic error in estimated GFR, is defined as the median or mean of the differences between estimated and measured GFR. The analysis was performed using $\mathrm{R}$ for windows, version 3.1.1 (R-Cran project, http://cran.r-project.org/).

\section{ETHICAL APPROVAL}

All the procedures were carried out in accordance with the ethical standards of the institutional and/or national research committees and of the 1964 Helsinki Declaration and its later amendments or comparable ethical standards. An appropriate informed consent was signed by all the participants or their legal representatives. The consent form contained information on the procedure itself as well as on the possible use of the data for research purposes. According to the current French laws, an observational study that does not change routine management of patients does not need to be declared or submitted to a research ethics board (Loi Huriet-Sérusclat 88-1138, 20 December 1988 and its subsequent amendments, text available at http://www.chu-toulouse.fr/IMG/pdf/loihuriet. pdf).

\section{RESULTS}

The patient clinical characteristics are listed in the Table 1. The mean age and BMI were 50.0 [IQR, 40.0-63.0] years and 25.3 [IQR, 22.3-32.0] $\mathrm{kg} / \mathrm{m}^{2}$, respectively.

The Table 1 and Figure 1 show the performance of the CKD-EPI equation versus iohexol. CKD-EPI equation had a mean error of $-3.0(95 \% \mathrm{CI},-7.0$ to $-0.5) \mathrm{mL} / \mathrm{min} / 1.73 \mathrm{~m}^{2}$ without statistical difference to GFR. Therefore, the use of CKD-EPI in patients without mGFR could be adequate for evaluation of POx levels.

For all but one patient with mGFR, the POx concentration was $<5 \mu \mathrm{mol} / \mathrm{L}$. One patient had abnormal values of POx $(7 \mu \mathrm{mol} / \mathrm{L})$ with a mGFR of $30 \mathrm{~mL} /$ $\min / 1.73 \mathrm{~m}^{2}$. Among the 14 patients with severe CKD (GFR $<30 \mathrm{~mL} / \mathrm{min} / 1.73 \mathrm{~m}^{2}$ ), four patients showed a slightly increased POx (between 6 and $12 \mu \mathrm{mol} / \mathrm{L}$ ) (Table 1).

\section{Discussion}

POx can increase in CKD due to the reduced GFR and secretion of the proximal renal tubules. ${ }^{1,2,15-18}$ However, few authors have specifically studied the
TABLE 1 Characteristics of THE PATIENTS

\begin{tabular}{|c|c|}
\hline Number of participants & 72 \\
\hline Age (years) & $50[40 ; 63]$ \\
\hline Male & $40(56.3)$ \\
\hline \multicolumn{2}{|l|}{ Diagnosis } \\
\hline CKD & 60 (83) \\
\hline $\begin{array}{l}\text { Candidate for living kidney } \\
\text { donation }\end{array}$ & $12(17)$ \\
\hline Weight (kg) & $72.0[60.5 ; 90.0]$ \\
\hline Height (cm) & 168.0 [160.0; 174.5] \\
\hline Body surface area $\left(\mathrm{m}^{2}\right)$ & $1.83[1.63 ; 2.01]$ \\
\hline Body mass index $\left(\mathrm{kg} / \mathrm{m}^{2}\right)$ & $25.3[22.3 ; 32.0]$ \\
\hline $\begin{array}{l}\mathrm{mGFR}\left(\mathrm{mL} / \mathrm{min} / 1.73 \mathrm{~m}^{2}\right) \\
(\mathrm{n}=62)\end{array}$ & $74.5[53.0 ; 91.0]$ \\
\hline eGFR (mL/min/1.73 m²) & $70.0[39.0 ; 96.0]$ \\
\hline $\begin{array}{l}\text { mean mGFR-eGFR } \\
(95 \% \mathrm{Cl}), \mathrm{mL} / \mathrm{min} / 1.73 \mathrm{~m}^{2} \\
(\mathrm{~N}=62)\end{array}$ & $-3.8(-7.0 ;-0.5)$ \\
\hline \multicolumn{2}{|l|}{ Plasma oxalate } \\
\hline Plasma oxalate $<5 \mu \mathrm{mol} / \mathrm{L}$ & $67(93.0)$ \\
\hline Plasma oxalate $\geq 5 \mu \mathrm{mol} / \mathrm{L}$ & $5(7.0)$ \\
\hline \multicolumn{2}{|l|}{ CKD stages } \\
\hline Stage I & $16(22.2)$ \\
\hline Stage II & 28 (38.9) \\
\hline Stage IIla & $4(5.5)$ \\
\hline Stage IIIb & $10(13.9)$ \\
\hline Stage IV & $11(15.3)$ \\
\hline Stage V & $3(4.0)$ \\
\hline
\end{tabular}

Figure 1. Glomerular filtration by iohexol and age (years) of the study participants.

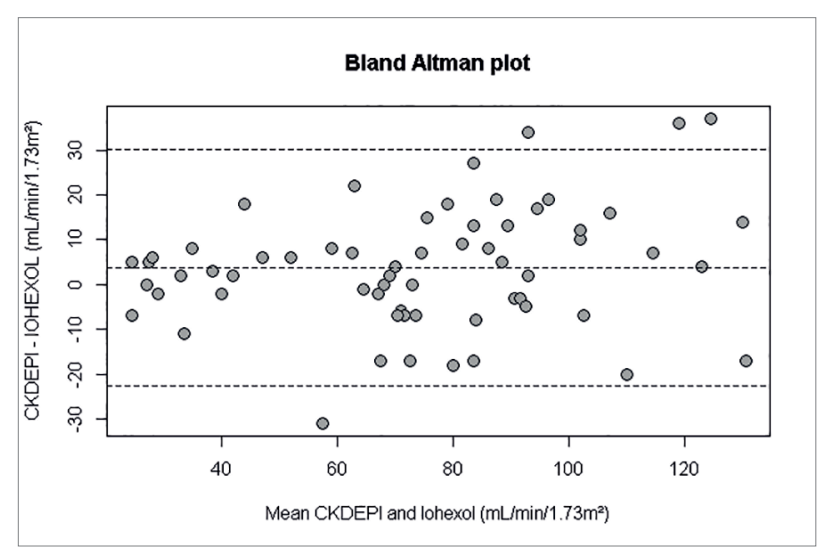

correlation between POx and GFR stage., ${ }^{75-20}$ In addition, some authors established a POx threshold level that differentiate $\mathrm{PH}$ from other causes of $\mathrm{POx}$ increase. ${ }^{1,2}$ 
Constable et al. reported that POx was raised by a factor of 10 in $\mathrm{PH}$ subjects who still had good renal function..$^{18}$ By contrast, Morgan et al. demonstrated in patients with non-PH-CKD that oxalate retention is increased when GFR is below $20 \mathrm{~mL} / \mathrm{min} / 1.73 \mathrm{~m}^{2} .^{20}$ In the same way, Constable et al. reported that the oxalate metabolic pool expands rapidly when the GFR is under $25 \mathrm{~mL} / \mathrm{min} / 1.73 \mathrm{~m}^{2}$, which is in accord with our results. Barratt et al. found that POx is also increased in end stage renal disease (ESRD). ${ }^{19}$ Bhasin et al. reported that $\mathrm{POx}$ was higher than $80 \mu \mathrm{mol} / \mathrm{L}$ in PH patients with ESRD. ${ }^{1,2}$ Elgstoen et al. found that median POx before transplantation was $35.0 \mu \mathrm{mol} / \mathrm{L}$ (95\% CI: 10.4 to 93.9 ) and $98 \%$ of the values were above normal limits. ${ }^{11}$

In the present study, we found a slightly increased POx with GFR $<30 \mathrm{~mL} / \mathrm{min}$ per $1.73 \mathrm{~m}^{2}$, well above the level at which renal replacement is needed. However, we were not able to demonstrate a correlation between GFR and POx.

The strengths of the present study are i) the reference method (iohexol) for direct measurement of GFR for most of the patients; and ii) the wide ranges for GFR levels ( 7 to $139 \mathrm{~mL} / \mathrm{min} / 1.73 \mathrm{~m}^{2}$ ).

Study limitations are: i) the population sample included few patients with GFR $<30 \mathrm{~mL} / \mathrm{min} / 1.73$ $\mathrm{m}^{2}$, which did not allow establishing a correlation between POx and GFR.

\section{Conclusion}

This study suggests that POx increases significantly only in advanced stages of CKD. In our opinion, values greater than $5 \mu \mathrm{mol} / \mathrm{L}$ with an eGFR $>30 \mathrm{~mL} /$ $\mathrm{min} / 1.73 \mathrm{~m}^{2}$ are suggestive of $\mathrm{PH}$. However, new studies should determine the kinetics of POx in advanced CKD and dialysis patients.

\section{Declarations}

Conflict of interest: The authors have no conflicts of interest to disclose.

\section{References}

1. Bhasin B, Ürekli HM, Atta MG. Primary and secondary hyperoxaluria: Understanding the enigma. World J Nephrol 2015;4:235-44.
2. Cochat P, Rumsby G. Primary hyperoxaluria. N Engl J Med 2013;369:649-58.

3. Bagnasco SM, Mohammed BS, Mani H, Gandolfo MT, Haas M, Racusen LC, et al. Oxalate deposits in biopsies from native and transplanted kidneys, and impact on graft function. Nephrol Dial Transplant 2009;24:1319-25.

4. Rankin AC, Walsh SB, Summers SA, Owen MP, Mansell MA. Acute oxalate nephropathy causing late renal transplant dysfunction due to enteric hyperoxaluria. Am J Transplant 2008;8:1755-8.

5. Gregoriou S, Kalapothakou K, Kontochristopoulos G, Belyayeva H, Chatziolou E, Rigopoulos D. Subungual oxalate deposits in a patient with secondary hyperoxaluria. Acta Derm Venereol 2011;91:195-6.

6. Truong LD, Yakupoglu U, Feig D, Hicks J, Cartwight J, Sheikh-Hamad D, et al. Calcium oxalate deposition in renal allografts: morphologic spectrum and clinical implications. Am J Transplant 2004;4:1338-44.

7. Pinheiro HS, Câmara NO, Osaki KS, De Moura LA, Pacheco-Silva A. Early presence of calcium oxalate deposition in kidney graft biopsies is associated with poor long-term graft survival. Am J Transplant 2005;5:323-9.

8. Recht PA, Tepedino GJ, Siecke NW, Buckley MT, Mandeville JT, Maxfield FR, et al. Oxalic acid alters intracellular calcium in endothelial cells. Atherosclerosis 2004;173:321-8.

9. Salyer WR, Salyer DC. Oxaluric renal failure. N Engl J Med 1973;288:913

10. Salyer WR, Keren D. Oxalosis as a complication of chronic renal failure. Kidney Int 1973;4:61-6.

11. Elgstoen KB, Johnsen LF, Woldseth B, Morkrid L, Hartmann A. Plasma oxalate following kidney transplantation in patients without primary hyperoxaluria. Nephrol Dial Transplant 2010;25:2341-5.

12. Group KDIGOKCW. KDIGO 2012 clinical practice guideline for the evaluation and management of chronic kidney disease. Kidney Int Suppl 2013;3:1-150.

13. Petrarulo M, Cerelli E, Marangella M, Cosseddu D, Vitale C, Linari F. Assay of plasma oxalate with soluble oxalate oxidase. Clin Chem 1994;40:2030-4.

14. Bröchner-Mortensen J. A simple method for the determination of glomerular filtration rate. Scand J Clin Lab Invest 1972;30:271-4.

15. Cavalier E, Rozet E, Dubois N, Charlier C, Hubert P, Chapelle JP, et al. Performance of iohexol determination in serum and urine by HPLC: validation, risk and uncertainty assessment. Clin Chim Acta 2008;396:80-5.

16. Sikora P, Beck B, Zajaczkowska M, Hoppe B. Plasma oxalate level in pediatric calcium stone formers with or without secondary hyperoxaluria. Urol Res 2009;37:101-5.

17. Kadlec AO, Greco KA, Fridirici ZC, Gerber D, Turk TM. Effect of renal function on urinary mineral excretion and stone composition. Urology 2011;78:744-7.

18. Kasidas GP, Nemat S, Rose GA. Plasma oxalate and creatinine and oxalate/creatinine clearance ratios in normal subjects and in primary hyperoxaluria. Evidence for renal hyperoxaluria. Clin Chim Acta 1990;191:67-77.

19. Constable AR, Joekes AM, Kasidas GP, O'Regan P, Rose GA. Plasma level and renal clearance of oxalate in normal subjects and in patients with primary hyperoxaluria or chronic renal failure or both. Clin Sci (Lond) 1979;56:299-304.

20. Barratt TM, van't Hoff WG. Are there guidelines for a strategy according to glomerular filtration rate, plasma oxalate determination and the risk of oxalate accumulation? Nephrol Dial Transplant 1995;10:22-3.

21. Morgan SH, Maher ER, Purkiss P, Watts RW, Curtis JR. Oxalate metabolism in end-stage renal disease: the effect of ascorbic acid and pyridoxine. Nephrol Dial Transplant 1988;3:28-32. 